\title{
Types of temporal adverbials and the fine structure of events
}

\author{
Ferenc Kiefer
}

\section{Introduction}

Temporal adverbials have been widely used to identify the event type of predicates since at least Vendler (1967). However, in most work only for- and in-adverbials were used, for-adverbials to identify accomplishments and inadverbials to identify achievements. Moreover, these adverbials were used exclusively to define predicate classes, the internal structure of events was left out of consideration. In the present paper we are going to pursue three goals. First, by using time point adverbials (at five o'clock), temporal adverbials which denote the length of the consequent state (occupy sg for two hours) and temporal adverbials which delimit temporally an event but do not specify its duration (until five o'clock) in addition to the two traditionally employed adverbials, we will attempt to identify the maximal number of verb classes which are identifiable by means of these temporal adverbials. Second, we will also make use of the compatibility with temporal adverbials to define the event structure of these verbs types in terms of subevents and the temporal relations which hold between them. To be sure, not all aspects of event structure are directly deducible by means of the adverbial test. In some cases a subevent may be presupposed or implied. Third, it will be shown that aspect is derivable from event structure. Though we will restrict ourselves to the lexical representation of event structure, it will become clear that this cannot be done without taking into account the interplay between syntax and semantics. The compatibility with temporal adverbials can only be tested on the sentence level, and the compositionality of event structure, whereever it arises, is also a matter of syntax. The discussion will concentrate on Hungarian but it is hoped that much of what will be said carries over to other languages as well. ${ }^{1}$

\section{Types of adverbials and verb classes}

First, we will examine the compatibility of various verbs with five different types of temporal adverbials:

\footnotetext{
${ }^{1}$ The present paper is based on Chapter 4. in Kiefer (2006).
}

Adverbs and Adverbial Adjuncts at the Interfaces, 241-262

Katalin É. Kiss (ed.)

Copyright (C) 2009, Mouton de Gruyter, Berlin 


\section{Ferenc Kiefer}

(a) time span adverbials (e.g. két órán át 'for two hours'), which denote the length of an ongoing event;

(b) durative-delimitative adverbials (e.g. két óra alatt 'in two hours'), which denote a process or activity with culmination (termination);

(c) time point adverbials (e.g. két órakor 'at two o'clock'), which identify the time of a punctual event;

(d) adverbials denoting the length of a resulting state (e.g. két órára 'for two hours' $)^{2}$,

(e) adverbials denoting an endpoint of a process or activity (e.g. két óráig 'until two o'clock').

The importance of this fifth type of adverbial will become clear immediately. For the sake of brevity, in what follows we will refer to the various types of adverbials by using the letters (a)-(e). Furthermore, each verb class will be represented by a verb, which will be used as the name of the respective verb class. $^{3}$

\subsection{Statives: the verb pihen 'rest'}

Statives are compatible with (a), (c) and (e) but not with (b), (d). ${ }^{4}$

(1) a. Két órán á /két órakor /két óráig pihentem. two hour for /two o'clock-at / two o'clock-until rested 'I had a rest for two hours/at two o'clock/until two o'clock.'

b. *Két óra alatt /két órára pihentem. two hour in /two hour-for rested 'I had a rest in two hours/for two hours.'

The interpretation of the time point adverbial in (1) calls for some comments. To have a rest at two o'clock can only mean that this time point is part of the time interval of resting. It cannot mean that the resting event occurred at two o'clock. Rest is a durative verb hence if John rests (has a rest) for two hours it must be true that John rests at any time point of this interval. In other words,

${ }^{2}$ Note that - in contrast to for -adverbials in English, which are ambiguous - Hungarian uses two different forms to express the two meanings: the postposition át is used in the case of time span adverbials and the case suffix -ra with adverbials denoting the length of a resulting state.

${ }^{3}$ Most verbs which we have taken as representatives of a verb class were discussed in various works on aspect and/or event structure.

${ }^{4} \mathrm{We}$ will not provide complete morphological information in the glosses. 
the time point adverbial cannot identify any distinct subevent in the case of states. As for the other two temporal adverbials note that some states may terminate, if one rests for two hours, the state of resting ends after two hours and the endpoint of resting may be denoted by a temporal adverbial. Since all statives are atelic, the termination of a state does not lead to a change of state.

\subsection{Processes, activities: the verb fut 'run'}

Processes and activities are like statives: they are compatible with (a), (c) and (e), but not with (b) and (d).

(2) a. Két órán át /két órakor /két óráig futottam. two hour for /two o'clock-at/two o'clock-until was.running 'I was running for two hours/at two o'clock/until two o'clock.'

b. *Két óra alatt/két órára futott. two hour in /two hour-for was.running 'He was running in two hours/for two hours.'

Since there are no further candidates which could do the job, statives and processes/activities cannot be kept apart by means of temporal adverbials, which, of course, does not mean that they have the same temporal properties. ${ }^{5}$

As for the interpretation of the time point adverbial, it is similar to what we had in the case of statives. John's running cannot be a punctual event since run, too, is a durative verb. And if John is running for two hours then he is running at most time points during this time interval. Consequently, the time point adverbial does not identify any distinct subevent.

\subsection{Accomplishments: the verb megir 'write down'}

Accomplishment verbs are compatible with (b), (c) and (e), but not with (a) and (d).

${ }^{5}$ The criteria proposed in the literature (e.g. Dowty 1979) for separating statives and activities do not work properly in Hungarian, however, we may use the adverb javában '[to be] in the middle of [doing something]; [to be] busy [doing something]' for this purpose, which works perfectly: *Péter javában látta a csillagot 'Peter was in the middle of seeing the star' - Péter javában olvasott 'Peter was busy reading'. The adverb javában stresses the fact that something is going on and it is incompatible with temporal adverbials of type (a) and (e), however, it may cooccur with a time point adverbial, as in Péter két órakor javában olvasott 'Peter was in the middle of reading at two o'clock'. 
(3) a. Két óra alatt /két órakor |két óráig megirta two hour in /two o'clock-at /two o'clock-until PRT-wrote a levelet. $^{6}$

the letter-ACC

'He wrote the letter in two hours/at two o'clock/until two o'clock.'

b. *Két órán át /két órára megírta a levelet.

two hour-for / two hour-for PRT-wrote the letter-ACC

'He wrote the letter for two hours.'

2.4. Achievements: the verb elér 'reach'

Achievements are compatible with (b), (c) and (e), but not with (a) and (d).

(4) a. Két óra alatt /két órakor /két óráig

two hour in /two o'clock-at/two o'clock-until

elérték a hegycsúcsot.

PRT-reached the top-ACC

'They reached the top in two hours/at two o'clock/until two o'clock.'

b. *Két órán át /két órára elérték a hegycsúcsot.

two hour for /two hour-for PRT-reached the top-ACC

'They reached the top for two hours.'

Since both verbs megir 'write down' and elér 'reach' are telic 8 the until adverbial denotes the final time point at which the event is successfully terminated, i.e. the relevant change of state is brought about.

At first glance it would seem that accomplishment and achievement verbs are indistinguishable by means of temporal adverbials. On a closer look, however, it turns out that this is not the case. Note that the time point adverbial means two different things in the case of the two verb classes. The relevant examples are repeated in (5) and (6).

(5) Két órakor megirta a levelet.

'He wrote the letter at two o'clock.'

(6) Két órakor elérték a hegycsúcsot.

'The reached the top at two o'clock.'

${ }^{6}$ 'PRT' denotes the verbal particle, which, among other things, turns an activity verb into an accomplishment verb. Particle verbs are normally aspectually perfective.

${ }^{7}$ In both senses of the adverbial.

${ }^{8}$ Both verbs are morphologically complex; they contain a verbal particle: $m e g+i r$, $1 e l+e ́ r$. 
In (5) the adverbial 'at two o'clock' cannot mean that the event of writing down the letter occurred in a moment. It can only mean that the writing of the letter started at two o'clock. This interpretation can be made explicit by paraphrases containing a verbal form with the meaning 'begin', as in (7).

(7) Két órakor hozzáfogott a levél megírásához. two o'clock-at started the letter writing-ALL 9 'He has started writing the letter at two o'clock.'

The situation is similar in the case of (8a), which can be paraphrased as in (8b).

(8) a. Nyolc órakor megnézte a filmet.

eight o'clock-at PRT-saw the film-ACC

'He saw the film at eight o'clock.'

b. Megnézte a nyolc órakor kezdödö filmet. saw the eight o'clock-at starting film-ACC

'He saw the film that started at eight o'clock.'

This means that we can in no way say that the event of writing the letter occurred at two o'clock and that the event of seeing the film occurred at eight, the time point adverbial does not identify any subevent. In other words, neither sentence (5) nor sentence (8a) can be interpreted literally, they are sloppy ways of conveying (7) and (8b), respectively. This means that accomplishment verbs are incompatible with time point adverbials.

The situation is different with (6), where the time point 'two o'clock' defines the occurrence of an event: the subevent of reaching the top.

As shown by their compatibility with durative-delimitative adverbials, accomplishments and achievements consist of a durative process or activity and of a culmination, which, however, can only be identified as a subevent in the case of achievements.

The fact that both accomplishments and achievements are compatible with durative-delimitative adverbials shows that both must involve a process or activity. At the same time they also show that they have not only a culmination point but also a resulting state. This will follow from the meaning of the durativedelimitative adverbials, as shown further below. All accomplishment and achievement verbs are change of state verbs. ${ }^{10}$

\subsection{Megáll 'stop' type verbs}

The verb megáll is compatible with (b), (c) and (d), but not with (a) and (e).

\footnotetext{
9'ALL' denotes the allative case suffix.

${ }^{10}$ Cf. Pustejovsky (1991: 57-58).
} 
(9) a. A vonat két perc alatt/két percre /két órakor the train two minute in /two minute-for/two o'clock-at megállt.

PRT-stopped

'The train stopped in two minutes/for two minutes/at two o'clock.'

b. *A vonat két percen át /két óráig megállt.

the train two minute for /two o'clock-until PRT-stopped

'The train stopped for two minutes/until two o'clock.'

The adverbial 'at two o'clock' identifies a punctual stopping event. Due to the fact that (9a) contains a durative-delimitative adverbial, the event described by the sentence must have a process or activity phase as well. What makes megáll 'stop' dissimilar from achievement verbs is its compatibility with (d), which denotes the length of the consequent state.

\subsection{Elborozgat 'spend the time by drinking wine' type verbs}

The verb elborozgat is compatible with (e), but not with (a)-(d). Though there are other verb types which are compatible with (e), (e) is the only adverbial type admitted by elborozgat. This is the reason why it was important to add (e) to the list of temporal adverbials.

The verb elborozgat is derived from the noun bor 'wine', from which the verb boroz(ik) 'drink wine' is derived; -gat is a suffix with a deminutive meaning, which yields borozgat 'take a glass or two of wine'. This form can be prefixed by the particle $e l$, which has a delimitative-perfective meaning: the activity is temporally delimited. The verb has thus the following morphological structure: $\left[\mathrm{el}_{\mathrm{PRT}}\left[\left[\right.\right.\right.$ bor $\left.\left.\left.\left._{\mathrm{N}}\right] \mathrm{oz}_{\mathrm{V}}\right] \mathrm{gat}_{\mathrm{V}}\right]\right]$; the pattern is highly productive. ${ }^{11}$

(10) a. Késö estig elborozgattak.

late evening-until PRT-drank.wine

'They drank wine until late at night.'

b. *Két órán át /két óra alatt/két órára /két órakor two hour for /two hour in /two hour-for/two o'clock-at elborozgattak.

PRT-drank.wine

'They drank wine for two hours/in two hours/for two hours/at two o'clock.'

\footnotetext{
${ }^{11}$ The verb elborozgat represents one of the aktionsarten in Hungarian. As in Slavic, in Hungarian, too, all aktionsarten are derived by morphological means (prefixation, suffixation). Aspect and aktionsart are two different notions.
} 
That there is an activity going on during a certain time, which eventually leads to an endpoint, can be shown by examples such as (11).

(11) Kettöl háromig elborozgattak. two-from three-until PRT-drank.wine 'They drank wine from two to three.'

\subsection{Tüsszent 'sneeze' type verbs}

The verb tüsszent 'sneeze' is compatible with (a), (c) and (e), but not with (b), (d).

Tüsszent 'sneeze' is a punctual verb, the occurrence of the sneezing event can be identified by means of a time point adverbial. ${ }^{12}$ At the same time, this verb is compatible with time span and endpoint adverbials as well.

(12) a. Két órakor tüsszentett. two o'clock-at sneezed

'He sneezed at two o'clock.'

b. Két órán át tüsszentett. ${ }^{13}$ two hour for sneezed 'He was sneezing for two hours.'

c. Két óráig tüsszentett.

two o'clock-until sneezed

'He was sneezing until two o'clock.'

While sentence (12a) denotes one single punctual sneezing event, (12b) and (12c) express a series of punctual sneezing events. ${ }^{14}$ The iterative reading is imposed on the predicate by the temporal adverbial.

For obvious reasons, the verb tüsszent is incompatible with (b) and (d).

2.8. Feljajdul 'cry out in pain' type verbs

The verb feljajdul 'cry out in pain' is compatible with (c) only.

\footnotetext{
${ }^{12}$ Smith (1991) calls 'sneeze' and similar punctual verbs 'semelfactive'. Note that this term is used to denote a special type of aktionsart in Slavic linguistics. Punctual verbs are not all semelfactive in Smith's sense, as we shall see presently.

${ }^{13}$ The Hungarian verb has no progressive form: the verb forms in (12a) and (12b) are identical, the different interpretation is due to the different time adverbials.

${ }^{14}$ Hungarian is not different from English in this respect.
} 
The verb feljajdul is a punctual verb, the crying out event can be identified by a time point adverbial. In contrast to 'sneeze', however, it does not admit time span adverbials, consequently it can never get an iterative meaning.

\section{a. Két órakor feljajdult.} two o'clock-at out-cried

'He cried out in pain at two o'clock.'

b. *Két órán át feljajdult.

two hour for out-cried

'He cried out in pain for two hours.'

Once again, for obvious reasons the verb feljajdul is incompatible with (d) and (e).

Both punctual verbs, sneeze and cry out, denote events which do not presuppose any preceding process and do not lead to a resulting state. This is shown by the incompatibility of these verbs with (b), see below.

\subsection{Eltörik 'break' type verbs}

The verb eltörik 'break' is compatible with (c), but not with (a), (b), (d) and (e).

The verb eltörik is once again a punctual verb, but it is also a change of state verb. This means that we must assume that there is a consequent state though this state cannot be identified by any temporal adverbial. All change of state verbs must be characterized lexically for this property.

(14) Két órakor a váza eltörött. two o'clock-at the vase PRT-broke

'The vase broke at two o'clock.'

\subsection{Portalanit 'dust' type verbs}

The verb portalanit is compatible with (a), (b) and (c), but not with (d) and (e). Two groups of verbs belong here, both can be defined by morphological criteria. The verb portalanit is derived from the noun por 'dust', to which the negative suffix -talan is attached, which yields the adjective portalan 'dustless'. From that adjective the verb portalanit lit. 'to make dustless' is derived by means of the suffix -it. This a productive derivational pattern. The second group contains verbs of foreign origin containing the derivational suffix -izál or -ál: e.g. modern\#izál 'modernize', telefon\#ál 'phone, call'. The compatibility behavior of the verbs of these two groups can be predicted on the basis of their morphological structure. 

(15) a. Két órakor portalanitott.
two o'clock-at dusted
'He was dusting at two o'clock.'
b. Két órán át portalanitott.
two hour-for dusted
'He was dusting for two hours.'
c. Két óráig portalanitott.
two o'clock-until dusted
'He was dusting until two o'clock.'
d. Két óra alatt portalanitotta a lakást.
two hour-in dusted the apartment
'He dusted the apartment in two hours.'

Portalanit is a process verb, hence the compatibility with (a) and (e) is what we would expect. (15c), however, has an accomplishment reading, as shown by adverbial (b). Lexically the verb is certainly not ambiguous. Consequently, the accomplishment reading must be derived compositionally and the verbs in question have to be marked lexically to this effect. ${ }^{15}$

\subsection{Végigül 'sit through' type verbs}

The verb végigül does not admit any of the adverbials (a)-(e). The verb class is defined by the complete lack of compatibility with temporal adverbials. The reason for this particular behavior is evident: the verbs in question require an object argument denoting an event, which, too, has a temporal structure, hence it functions as a temporal modifier.

\section{(16) Végigülte az elöadást. \\ end-to-sat the performance-ACC \\ 'He sat through the performance.'}

The performance has a certain duration and this duration defines the duration of the sitting-event. Since a sentence admits only one temporal modifier expressing duration, the sitting event cannot be temporally specified by means of a temporal adverbial. ${ }^{16}$

\footnotetext{
${ }^{15}$ In this respect portalanit-type verbs are similar to 'verbs of creation'.

${ }^{16}$ Of course, deictic temporal adverbs are not a problem: Yesterday he sat through the performance. For a detailed discussion of verbs with the particle végig 'to the end' cf. Piñon (2000).
} 


\subsection{Conclusion}

On the basis of various temporal adverbials we have identified eleven verb classes. Our results are summarized in Table 1. We will refer to each verb class by means of the verb representing it. Furthermore, we will leave out of consideration the compatibility with time point adverbials in the case of statives, processes and accomplishments, as well as in the case of the verb portalanit 'dust' since, as was shown above, it cannot identify a distinct subevent in these cases.

Table 1. The compatibility of verbs with temporal adverbials

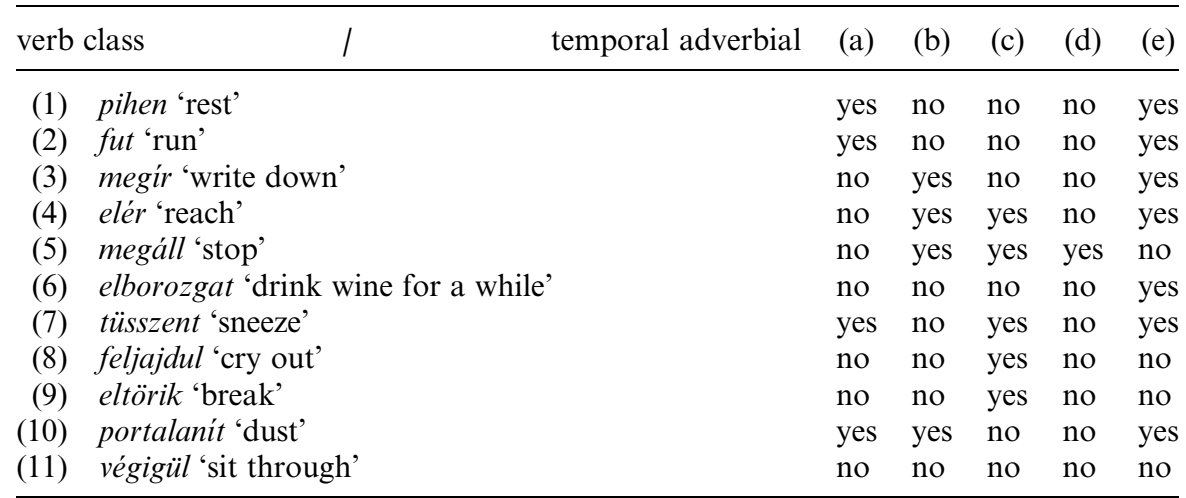

As can be seen, the following verb types can uniquely be determined by means of the compatibility test: (3), (4), (5), (6), (7), (10), (11). On the other hand, (1)(2) and (8)-(9) cannot be kept apart in this way. Concerning the distinction between states and activites, in Hungarian the adverbial javában '[to be] in the middle [of sg]' can be used to keep these two types apart. ${ }^{17}$ For the difference between (8) and (9) we have to rely on the semantics of these verbs. To use the terminology proposed by Moens and Steedman (1988), (8)-type verbs have neither a 'preparatory phase' nor a 'consequent state', while (9)-type verbs do have a 'consequent state'. In sum, then, we have identified eleven verb classes in Hungarian, which include all verb classes identifiable by means of temporal adverbials. ${ }^{18}$

${ }^{17}$ Cf. fn. 5 .

${ }^{18}$ We disregard individual cases such as the one represented by the verb túlél vkit 'outlive sb', which is compatible with an adverbial of type két évvel 'by two years' only: Két évvel túlélte a férjét 'She outlived her husband by two years'. This verb, however, does not respresent a verb class since it is the only verb of this type. 


\section{Event structure}

\subsection{Preliminaries}

We will assume - following Pustejovsky $(1991,1995)$ - that events may be composed of subevents and that the notion of event structure implies such a composition. It has also been proposed that subevents may be determined by various tests, which we will not repeat here. ${ }^{19}$ Though these tests are certainly useful to show that events may be composed of subevents, they cannot be used to systematically identify these subevents. In the present paper it will be claimed that this can be done to a large extent by means of temporal adverbials. Consequently, our task will be to find out what the compatibility with temporal adverbials can tell us about event structure.

Following Engelberg (2000), we will assume that there are three event types which cannot be traced back to anything else hence must be taken for being atomic: states, activities and punctual events, to be denoted by S, A and P, respectively. A state holds during a time interval without interruption, an activity (or process) is going on during a time interval allowing gaps, a punctual event occurs at a given time point and there is no other time point at which it occurs. The notion of 'change of state' will be used in the narrower sense: an activity does not involve a change of state but it may lead to a change of state (as in the case of accomplishments and achievements). The symbol $e$ will be used to refer to events; subevents will be denoted by subscripts: $e_{i}$. $\mathrm{S}(\mathrm{x}, \mathrm{e})$ will mean that the entity $x$ is in the state $\mathrm{S}, \mathrm{A}(\mathrm{x}, \mathrm{e})$ that the entity $x$ participates in the activity $\mathrm{A}$, and $\mathrm{P}(\mathrm{x}, \mathrm{e})$ that $x$ is the participant of a punctual event $\mathrm{P}$. The transitive variants are correspondingly $\mathrm{S}(\mathrm{x}, \mathrm{y}, \mathrm{e}), \mathrm{A}(\mathrm{x}, \mathrm{y}, \mathrm{e})$ and $\mathrm{P}(\mathrm{x}, \mathrm{y}, \mathrm{e})$. Examples for the basic event types are given in (17)-(19).

(17) János beteg 'John is ill' $\mathrm{S}$ (John, ill): 'John is in the state of being ill'

(18) János dolgozik 'John is working' A(John, working) 'John participates in the event of working'

(19) János elbotlott 'John stumbled' $\mathrm{P}(\mathrm{John}$, stumble) 'John was the participant of a stumbling event'

It has also been suggested that representations such as (17)-(19) should be complemented by the thematic protoroles of the participants. Thematic roles, too, can be represented as predicates over participants and events. ${ }^{20}$ Consequently,

${ }^{19}$ Cf. Pustejovsky (1991), and for a more detailed discussion Engelberg (2000: 48-54).

${ }^{20} \mathrm{Cf}$., for example, Engelberg (2000) and (2004). 
a more complete representation of the event structures (17)-(19) may look like (20)-(22).

(20) S(John, ill) \& Patient(John, ill): 'John is in the state of being ill and he is the Patient participant of this state'

(21) A(John, working) \& Agent(John, working): 'John participates in the event of working and he is the Agent participant of that event'

(22) P(John, stumble) \& Patient(John, stumble): 'John was the Patient participant of a stumbling event'

Since we are interested in identifying the event types and the subevents of events, we will leave thematic roles out of consideration in the present paper.

There may be various temporal relations between subevents: temporal precedence, immediate precedence, and temporal overlap, among other things. ${ }^{21}$ In what follows we will be concerned with temporal precedence and temporal overlap only, to be denoted by ' $<$ ' and ' $\diamond$ ', respectively.

Before embarking on the discussion of event structure, let us have a closer look at the meaning of the various temporal adverbials in order to see what kind of conclusions we can draw from their semantics with respect to event structure.

\subsection{The meaning of temporal adverbials}

We have been using five temporal adverbials for finding out how many different verb classes can temporally be defined. In what follows we will see how temporal adverbials can be used to identify (sub)events.

\subsection{1. Át 'for time $\mathrm{t}$, during time $\mathrm{t}$ ' adverbials (type (a))}

These adverbials can be used to identify states, activities and processes. However, they provide only a sufficient, and not a sufficient and necessary, condition for processhood. If a predicate is compatible with (a) only, it must denote either a state or a process. The process involved in the case of accomplishment

\footnotetext{
${ }^{21}$ Engelberg (2004) distinguishes five temporal relations. In addition to the ones just mentioned, he postulates two more relations: something like 'the event starts earlier' and 'precedence with overlap'. The linguistic evidence for their postulation is not very convincing, however.
} 
and achievement predicates cannot be identified by means of (a). Neither can it be done in the case of portalanit 'dust', megáll 'stop', elborozgat 'drink wine', and végigül 'sit through' type verbs. In other words, the temporal adverbial (a) cannot be used to identify process-subevents. However, if it is the only adverbial applicable, the verb must either be a stative or an activity/process verb.

\subsubsection{Alatt 'in time $\mathrm{t}$ ' adverbials (type (b))}

The predicates with which these adverbials are compatible must denote a process which leads to a new state. The change-of-state meaning leading to a new state is a typical feature of these predicates. The resulting state cannot be identified directly by means of temporal adverbials, they appear rather as implications. For example, János megírta a levelet 'John has written the letter' implies that the letter has been finished. The change of state can be described by saying that at the initial state there was no letter and at the final state there was a letter. Consequently, (b) may be used to identify two subevents: a process and a state. The compatibility with (b) thus tells us that accomplishment and achievement type verbs as well as megáll 'stop' and portalanit 'dust' type verbs must contain at least two subevents: a process-event and a state-event. In the case of megáll, the process event can also be considered to be presupposed: both Az autó megállt 'The car stopped', and Az autó nem állt meg 'The car did not stop' presuppose that the car was moving. Note that though they denote a change of state, eltörik 'break' type verbs are not compatible with (b). This means that compatibility with (b) works only in one direction.

\subsubsection{Time point adverbials 'at time point t' (type (c))}

The time point adverbial (in the strict sense) denotes the fact that an event occurred precisely at the time point denoted by the adverbial. If (c) is the only adverbial with which the predicate is compatible, then it must denote a punctual event. This is the case with feljajdul 'cry out in pain' and eltörik 'break' type verbs. If the predicate is compatible with other types of adverbials as well, it must contain a punctual subevent in its event structure. This is the case with achiements and the megáll 'stop' type of verbs.

What about the sneeze 'tüsszent' type? They, too, are compatible with (c) type adverbials, at the same time, however, they also admit (a) and (e) type adverbials. This seems to be a contradiction since processes and punctual events are incompatible with each other. The apparent contradiction disappears if we 


\section{Ferenc Kiefer}

realize that tüsszent 'sneeze' is a punctual event from which another 'situation type' can be derived. ${ }^{22}$

No doubt, we have to do here with a rather special type of verbs, which have to be marked to this effect in the lexicon, since - in contrast to English - other types of punctual verbs do not make the derivation of a process reading possible.

(23) *Órákon át feljajdult.

'He was crying out in pain for hours. ${ }^{.23}$

(24) *A váza órákon át eltörött.

'The vase broke for hours.'

In Hungarian it is possible to derive a verb with a repetitive meaning by means of the reduplication of the particle. ${ }^{24}$ Such verbal constructions always yield a process reading though the base denotes a punctual event. ${ }^{25}$

(25) Órákon át fel-feljajdult.

'He was crying out in pain for hours.'

The fact that eltörik 'break' type verbs do not admit a derived reading can easily be explained: the event of breaking leads to an irreversible resulting state.

\subsection{4. $t$ idöre 'for time t' adverbials, denoting the length of a state following an event (type $(d)$ )}

The English examples below show what is at stake here. ${ }^{26}$

(26) a. Mary ran into the house for twenty minutes.

b. John left for a week.

Hungarian does not behave differently in this respect. However, as is wellknown, not all change-of-state verbs admit adverbial (d). It is certainly true that the resulting state must be reversible for (d) to be applicable: (27a) is grammatical, (27b) is definitely odd.

\footnotetext{
${ }^{22}$ Smith considers the derived readings to be a consequence of the incompatibility of the meaning of the predicate and the temporal adverbial. The punctual event reading of Mary coughed and the durative reading of for an hour are incompatible, therefore the temporal adverbial gives rise to an iterative reading of the predicate. Repetitive events are always process-like. Cf. Smith (1991).

${ }^{23}$ The English translation of the Hungarian sentence is, of course, grammatical.

${ }^{24}$ Cf. Kiefer (1995-1996) on particle reduplication in Hungarian.

${ }^{25}$ This is, of course, not the same thing as Smith's derivation.

${ }^{26}$ Cited from Pustejovsky (1991).
} 

(27)
a. Fél órára elszundított.
half hour-for PRT-fell.asleep
'He fell asleep for half an hour.'
b. *Fél órára kivasalta az ingét.
half hour-for PRT-ironed the shirt-his-ACC
'He ironed his shirt for half an hour.'

On the other hand, examples $(28 \mathrm{a}, \mathrm{b})$ show that reversibility is not a sufficient condition for compatibility with (d). ${ }^{27}$
(28) a. *Ellopták öt napra a pénztárcámat.
'They stole my briefcase for five days.'
b. * Öt napra betegre verték.
'They beat him hollow for five days.'

It follows that adverbial (d) cannot be used to identify the resulting state. It remains true, however, that if a predicate is compatible with (d), the event structure of the predicate must contain a subevent which expresses such a state.

\subsection{5. $t$ idôig 'until time point t' adverbials, expressing the endpoint of a process or activity (type (e))}

An adverbial (e) may denote the end of a state (He loved her until the end of last year), the end of a process or activity (He was working until six o'clock'), the endpoint of the completion of a task (He wrote the letter until six o'clock, They reached the top until six o'clock), the end point of an iterative event (He was sneezing until noon). However, there seems to be a clear difference between two interpretations of (e) in the above sentences. In the case of states and processes it clearly indicates the end of a state or a process: we cannot say that he was ill until yesterday when he, in fact, was already OK the day before yesterday. Similarly, we cannot say that he was working until six o'clock when he, in fact, finished working at four. On the other hand, in the case of accomplishments and achievements (e) is a kind of deadline: the letter may have been ready or they may have reached the top much before six o'clock. In this case the meaning of (e) is 'not later than'. In both cases, however, the compatibility with (e) proves the existence of a process. This process can also be considered to be a presupposition: A fiúk éjfélig elborozgattak 'The boys were drinking wine until midnight' - A fiúk nem borozgattak el éjfélig 'The boys did not drink wine until midnight'. The latter clearly means that the boys were drinking wine but not until midnight.

\footnotetext{
${ }^{27} \mathrm{Cf}$. Gyuris (2003) for some discussion of this problem.
} 
Adverbial (e) has a distinctive role in the case of elborozgat 'drink wine' type verbs since it is the only temporal adverbial with which these verbs are compatible. In fact, these verbs require a delimiting time adverbial.

(29) a. Mit csináltatok az irodában?

what did-you the office-in

'What did you do in the office?'

b. ??Elborozgattunk.

'We were spending our time by drinking wine.'

(30) a. Mit csináltatok tegnap este az irodában?

what did-you yesterday evening the office-in

'What did you do in the office last night?'

b. Elborozgattunk egy kicsit.

'We were drinking wine for a while.'

Time adverbial (e), however, does not only identify the activity subevent of the event of drinking wine for a while but it also refers to the endpoint of that activity. The verbs in question all contain the preverb el-, which renders them telic.

\subsection{The event structure of verb classes (a)-(e)}

In this section we are going to sum up what we learnt about event structure in the previous section.

3.3.1. States and processes/activities have no subevents. States can be represented by $\mathrm{S}(\mathrm{x}, \mathrm{e})$ and processes/activities by $\mathrm{A}(\mathrm{x}, \mathrm{e})$.

3.3.2. Accomplishments contain two subevents, a process or activity subevent and a resulting state. It goes without saying that the process/activity subevent must precede the stative subevent, hence we get: ${ }^{28}$

(31) $\mathrm{A}\left(\mathrm{x}, \mathrm{e}_{1}\right)<\mathrm{S}\left(\mathrm{x}, \mathrm{e}_{2}\right)$

3.3.3. Achievement verbs contain three subevents: a process or activity, a punctual event and a resulting state, in that order.

(32) $\mathrm{A}\left(\mathrm{x}, \mathrm{e}_{1}\right)<\mathrm{P}\left(\mathrm{x}, \mathrm{e}_{2}\right)<\mathrm{S}\left(\mathrm{x}, \mathrm{e}_{3}\right)$

3.3.4. Megáll 'stop' type verbs have the same event structure as achievement verbs, the difference between them is that in the case of megáll the length of the

${ }^{28}$ In the representations we will restrict ourselves to the intransitive cases. 
resulting state is controllable by an Agent. This property can be added as an additional feature of the representation, as in (33).

$$
\text { (33) } \mathrm{A}\left(\mathrm{x}, \mathrm{e}_{1}\right)<\mathrm{P}\left(\mathrm{x}, \mathrm{e}_{2}\right)<\left[\mathrm{S}\left(\mathrm{x}, \mathrm{e}_{3}\right) \& \exists \mathrm{y} \operatorname{CONTROL}\left(\mathrm{y}, \mathrm{e}_{3}\right)\right]
$$

Note, however, that, as to event structure proper, there is no difference between (32) and (33).

3.3.5. Elborozgat 'drink wine' type verbs must contain a process/activity subevent, shown by their compatibility with (e). It is equally clear that the event structure of these verbs must have at least one further subevent. If this were not the case, the predicate would be compatible with (a) type adverbials, too. The second subevent, however, cannot be identified by means of temporal adverbials. We cannot tell either what the temporal relation between the two subevents is. This leaves us with (34).

(34) $\mathrm{A}\left(\mathrm{x}, \mathrm{e}_{1}\right)$ ?

3.3.6. The verb tüsszent 'sneeze' is a punctual verb: $\mathrm{P}(\mathrm{x}$, tüsszent). The process reading must be derived compositionally, which shows that lexical event structure may change on the sentence level. Event structure is compositional just like aspect.

3.3.7. The verb feljajdul 'cry out in pain' differs from the tüsszent 'sneeze' type with respect to its compositional properties: it cannot be turned into a process by means of a time span adverbial; this can only be done by means of particle reduplication. With respect to event structure, however, the two verb classes are identical.

3.3.8. The verb eltörik 'break', too, denotes a punctual event. Normally, this event has no preparatory phase. If we assume, however, that someone was manipulating a vase for some time and then the vase broke, we can say $A$ váza öt perc alatt eltörött 'The vase broke in five minutes'. In that case the event consists of three subevents. Normally, however, the resulting state cannot be identified by means of temporal adverbials. Such a state follows from the fact that we have to do with a change-of-state verb. The compatibility test suggests that what we get is (35):

(35) $\mathrm{P}\left(\mathrm{x}, \mathrm{e}_{1}\right)<$ ?

3.3.9. The verb portalanit 'dust' is basically a process verb consisting of one single event $\mathrm{A}(\mathrm{x}, \mathrm{e})$; by means of a (b) type adverbial, however, it can be turned into an accomplishment. This has nothing to do with 'derived situation types', 
it is simply a matter of compositional semantics. To be sure, the verbs that admit this change in interpretation must be marked in the lexicon.

3.3.10. For semantic reasons discussed further above végigül 'sit through' type verbs do have an event structure, but none of the subevents are identifiable by means of temporal adverbials.

In view of the above observations we must conclude that the semantic verb classes established on the basis of compatibility with temporal adverbials are not identical with the types of event structure which can be identified by the same tests.

\section{Event structure and aspect}

Let us now summarize the types of event structure we get by means of temporal adverbials (Table 2.). The verb types which have identical event structure will not be listed separately.

Table 2. Event structures identifiable by means of temporal adverbials

\begin{tabular}{ll}
\hline Verb type & Event structure \\
\hline 1. pihen 'rest' & $\mathrm{S}(\mathrm{x}, \mathrm{e})$ \\
2. fut 'run', portalanit 'dust' & $\mathrm{A}(\mathrm{x}, \mathrm{e})$ \\
3. megir 'write down' & $\mathrm{A}\left(\mathrm{x}, \mathrm{e}_{1}\right)<\mathrm{S}\left(\mathrm{x}, \mathrm{e}_{2}\right)$ \\
4. elér 'reach', megáll 'stop' & $\mathrm{A}\left(\mathrm{x}, \mathrm{e}_{1}\right)<\mathrm{P}\left(\mathrm{x}, \mathrm{e}_{2}\right)<\mathrm{S}\left(\mathrm{x}, \mathrm{e}_{3}\right)$ \\
5. elborozgat 'drink wine for a while' & $\mathrm{A}(\mathrm{x}, \mathrm{e})$ ? \\
6. tüsszent 'sneeze', feljajdul 'cry out in pain' & $\mathrm{P}(\mathrm{x}, \mathrm{e})$ \\
7. eltörik 'break' & $\mathrm{P}\left(\mathrm{x}, \mathrm{e}_{1}\right)<$ ? \\
8. végigül 'sit through' & $? ?$ \\
\hline
\end{tabular}

Before embarking on the discussion of the relationship between event structure and aspect, we will first eliminate the question marks in Table 2. This can be done in a straightforward way in the case of eltörik 'break', which is a changeof-state verb, consequently its event structure must contain a subevent denoting the resulting state (' $\mathrm{x}$ is broken'), hence the event structure of 7. eltörik 'break' looks like (36):

(36) $\mathrm{P}\left(\mathrm{x}, \mathrm{e}_{1}\right)<\mathrm{S}\left(\mathrm{x}, \mathrm{e}_{2}\right)$ 
Elborozgat 'drink wine' type verbs express the delimitative aktionsart, which we may denote by DELIM(e), meaning 'e is a temporally delimited (bounded) atelic event'. We have to add DELIM(e) to the process-subevent: ${ }^{29}$

\section{(37) $\mathrm{A}(\mathrm{x}, \mathrm{e}) \& \operatorname{DELIM}(\mathrm{e})$}

The situation is more complex in the case of végigül 'sit through'. The sitting event and the performance event denoted by the deverbal noun, which binds the second argument of the verb, must have identical temporal extensions. The sitting event is of type $\mathrm{S}(\mathrm{x}, \mathrm{e})$ (the verb sit is stative), and the performance event is of type $\mathrm{A}(\mathrm{x}, \mathrm{e})$, and the activity not only has an endpoint but it leads to a new state. We can compare this case with the events described by János elolvasta a könyvet 'John has read the book (from beginning to end)' or Mária eljátszotta a szonátát 'Mary has played the sonata (from beginning to end), which bring about a new state. If we use the symbol ' $\diamond$ ' for overlapping events, we may represent the event structure of végigül 'sit through' in the following way.

(38) $\left[\mathrm{S}\left(\mathrm{x}, \mathrm{y}, \mathrm{e}_{1}\right) \diamond \mathrm{A}\left(\mathrm{x}, \mathrm{y}, \mathrm{e}_{2}\right)\right]<\mathrm{S}\left(\mathrm{x}, \mathrm{y}, \mathrm{e}_{3}\right)$

By having eliminated the question marks in Table 2. we get the following event structures:

Table 3. Verb types and their event structure

\begin{tabular}{ll}
\hline Verb type & Event structure \\
\hline 1. pihen 'rest' & $\mathrm{S}(\mathrm{x}, \mathrm{e})$ \\
2. fut 'run', portalanit 'dust' & $\mathrm{A}(\mathrm{x}, \mathrm{e})$ \\
3. megir 'write down' & $\mathrm{A}\left(\mathrm{x}, \mathrm{e}_{1}\right)<\mathrm{S}\left(\mathrm{x}, \mathrm{e}_{2}\right)$ \\
4. elér 'reach', megáll 'stop' & $\mathrm{A}\left(\mathrm{x}, \mathrm{e}_{1}\right)<\mathrm{P}\left(\mathrm{x}, \mathrm{e}_{2}\right)<\mathrm{S}\left(\mathrm{x}, \mathrm{e}_{3}\right)$ \\
5. elborozgat 'drink wine for a while' & $\mathrm{A}(\mathrm{x}, \mathrm{e})<\mathrm{DELIM}(\mathrm{e})$ \\
6. tiüsszent 'sneeze', feljajdul 'cry out in pain' & $\mathrm{P}(\mathrm{x}, \mathrm{e})$ \\
7. eltorik 'break' & $\mathrm{P}\left(\mathrm{x}, \mathrm{e}_{1}\right)<\mathrm{S}\left(\mathrm{x}, \mathrm{e}_{2}\right)$ \\
8. végigül 'sit through' & {$\left[\mathrm{S}\left(\mathrm{x}, \mathrm{y}, \mathrm{e}_{1}\right) \diamond \mathrm{A}\left(\mathrm{x}, \mathrm{y}, \mathrm{e}_{2}\right)\right]<\mathrm{S}\left(\mathrm{x}, \mathrm{y}, \mathrm{e}_{3}\right)$} \\
\hline
\end{tabular}

The event types of verbs determine the event types of sentences in which they occur. This is, of course, not always the case. As we saw above, tüsszent 'sneeze' type verbs, which are lexically punctual verbs, can be turned compositionally into process verbs, and portalanit 'dust' type verbs, which are lexically

${ }^{29} \operatorname{DELIM}(\mathrm{P})$ can properly be defined as follows: $\forall \mathrm{P}[\operatorname{DELIM}(\mathrm{P}) \leftrightarrow \forall \mathrm{x} \forall \mathrm{y}(\mathrm{P}(\mathrm{x}) \&(\mathrm{y} \subset \mathrm{x} \rightarrow \mathrm{P}(\mathrm{y})) \& \mathrm{x} \subset \mathrm{z} \rightarrow \neg \mathrm{P}(\mathrm{z}))]$ 
process verbs, can be turned compositionally into accomplishment verbs of type 3. We are not going to discuss the compositionality of event structure in more detail in the present paper. For simplicity's sake we are going to assume that the event structure of sentences is determined by the event structure of their verbs.

We are now in a position to have a closer look at the relationship between event structure and aspect. We will restrict ourselves to the two major aspectual categories 'perfective' and 'imperfective'. We define these notions by means of their subinterval properties. Let I be the time interval during which a situation holds: ${ }^{30}$

(39) a. A situation $\mathrm{G}$ is perfective if there is no subinterval of I during which $\mathrm{G}$ holds.

b. A situation $\mathrm{G}$ is imperfective if $\mathrm{G}$ holds at most subintervals of $\mathrm{I}$.

Or, to put it differently, perfective situations are characterized by an indivisible time interval whereas the time interval of imperfective situations is divisible. (39a, b) implies that a perfective event can only be true of the whole time interval I whereas an imperfective event may be true of any subinterval of I.

The time interval of a punctual event is certainly not divisible, hence predicates whose event structure consists of a single punctual event must be perfective. If an event structure contains two or more subevents, then each subevent must be assigned a different subinterval, i.e., the time interval of the event is split up into two or more subintervals. This means that the verb types mentioned in Table 3. under 4., 7., and 8. are perfective since the situations they describe cannot be true for most subintervals. This leaves us with verbs expressing the delimitative aktionsart which are neither punctual, nor do they contain two or more subevents. But the events in question are always delimited by a temporal adverbial. The situations they describe hold until their endpoint is reached, consequently the delimited event must be perfective.

Note that there is independent evidence for the perfectivity of these predicates. One way of showing this is to use a test first proposed by Kamp (1979), which was based on the observation that in a narrative text a 'perfective' event may move forward the sequence of events even if there is no temporal adverbial in the sentence, whereas in the case of an 'imperfective' event this is not possible. ${ }^{31}$ Consider, for example, $(40 \mathrm{a}, \mathrm{b})$.

\footnotetext{
${ }^{30}$ A similar definition has already been proposed by Dowty 1979.

${ }^{31}$ We know, of course, that this is a sufficient but not a necessary condition of perfectivity, however, the details of the problem need not concern us in the present paper.
} 
(40) a. Megirta a levelet és hazament.

'He wrote the letter and went home'

b. Megállt és körülnézett.

'He stopped and looked around'

In both cases the event described by the first conjunct must precede the event described by the second one.

We are now left with 1., 2., and 5. Divisible temporal intervals are a characteristic feature of states and activities, hence they are imperfective. As for 5., the predicate DELIM(e) seems to have the same effect on a process as a punctual subevent. The 'temporal sequence' test shows that elborozgat-type verbs must be perfective, too.

(41) Elborozgattak egy darabig és hazamentek. ${ }^{32}$

'They drank wine for a while and went home.'

In sum, then, all verb types except for 1. and 2. are perfective. Aspect can be read off from event structure.

\section{Conclusion}

In the present paper we have been using temporal adverbials in order to identify verb classes and we have found that (at least) nine such classes can be determined. This number significantly exceeds the number discussed earlier in the literature. ${ }^{33}$ The next question was to find out how compatibility with temporal adverbials relates to event structure. It turned out that five different event structures can be fully determined, two only partially and in one case nothing at all could be said about event structure on the basis of compatibility with temporal adverbials. ${ }^{34}$ In these cases we had to rely on the semantics of the verbs in question. In this way we ended up with eight different event structures. ${ }^{35}$ Finally, we were looking at the relationship between event structure and aspect. It was found that in most cases (if event structure consists of a single punctual event or if it contains two or more subevents) aspect automatically follows from event structure. It was also pointed out that if boundedness is properly defined, the perfectivity of delimitative verbs, too, can be read off from event structure.

\section{${ }^{32}$ Footnote Missing}

${ }^{33} \mathrm{Cf}$. Table 1 . Note that the verbs in (1) and (2) and (8) and (9) cannot be kept apart by means of the adverbial test.

${ }^{34} \mathrm{Cf}$. Table 2.

${ }^{35} \mathrm{Cf}$. Table 3. 


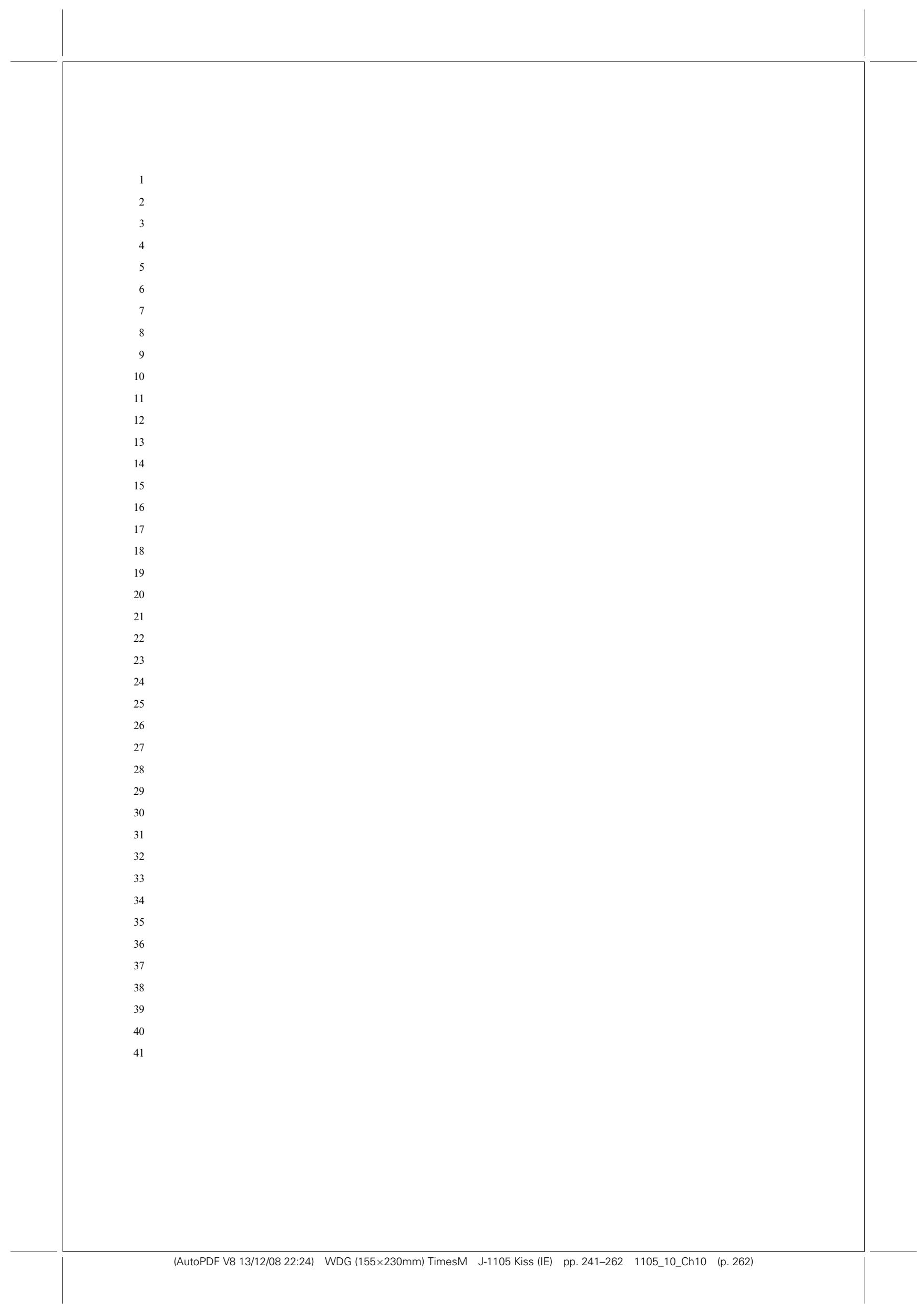

